\title{
The Strategy of Carrying out Ideological and Political Education in Curriculum of Introduction to Software Engineering
}

\author{
Ronghai Wang ${ }^{1,2,3,4, *}$, Yuzhu Zeng ${ }^{1,2,3,4}$ and Jingjing Yang 1, 2, 3,4 \\ ${ }^{1}$ Faculty of Mathematics and Computer Science, Quanzhou Normal University, Quanzhou, China \\ ${ }^{2}$ Fujian Provincial Key Laboratory of Data Intensive Computing, Quanzhou, China \\ ${ }^{3}$ Key Laboratory of Intelligent Computing and Information Processing, Fujian Province University, Quanzhou, China \\ ${ }^{4}$ Big Data Institute of Intelligent Manufacturing of Digital Fujian, Quanzhou, China \\ * Corresponding author E-mail: wrhai@163.com
}

\begin{abstract}
The integration of ideological and political elements into the curriculum is increasingly valued by schools. The study is aimed to present a strategy for implementing ideological and political education in curriculum of introduction to software engineering. Studying the implementation ideas of the ideological and political education in curriculum of introduction to software engineering, and then gives the key measures of the implementation of the ideological and political education in curriculum. Studying the curriculum knowledge content and the ideological and political education materials contained in it. Proposing the integration points of ideological and political mapping, and giving corresponding teaching method and expected results. The related teaching resources of ideological and political education in curriculum also are suggested. The teaching practice shows that after carrying out ideological and political education in curriculum, the students' sense of responsibility, hardworking attitude and spirit of unity and cooperation have been improved, and the students' academic achievements also have been improved.
\end{abstract}

Keywords-ideological and political education in curriculum; introduction to software engineering; key measures; integration points of ideological and political mapping; teaching resources

\section{INTRODUCTION}

Ideological and political education is an important part of school education. How to carry out ideological and political education effectively is a long-term and important research topic. Hong Lin studied the teaching strategies for the ideological and political course in colleges from the perspective of constructivism [1]. In the network era, college ideological and political education faces new opportunities and challenges. Making full use of the Internet, ideological and political education can complete the cycle from classroom teaching to network teaching and then back to classroom teaching. Teachers can fully play their guiding role and mobilize the enthusiasm of students to learn independently [2]. Xiangxue Kong studied the practical teaching mode of ideological and political theory courses in colleges and universities from the perspective of "broad ideology and politics” [3]. Yajuan Huang's research shows that the

This research was supported by Fujian Province Young Teachers Education Research Project under Grant JAT160399, and by Ideological and Political Education in Curriculum Reform Project of Faculty of Mathematics and Computer Science of Quanzhou Normal University under Grant sjsz1904. evaluation criteria and teaching effectiveness of college ideological and political theory courses should be clarified, and the evaluation index framework should be constructed according to the dimensions of teachers, students, environment and management [4]. Strengthening traditional virtue education also promotes the teaching of ideological and political courses [5].

In addition to the study of the ideological and political curriculum itself, the study of integrating ideological and political education into general courses and professional courses is also deepening constantly, which is called "ideological and political education in curriculum" in China. The key and core of effective curriculum integration is to find the integration point, establish a constructive internal fit relationship in a seamless and organic way, and establish the steps and logic of WWHF integration framework based on "why to integrate, merge what, how to integrate and effect feedback" [6]. Jinxing Shen et al. used the traffic environmental impact assessment course as an example to study the ideological and political education in curriculum of traffic engineering, and tried to evaluate the teaching practice and effect of ideological and political education in curriculum [7]. Under the idea of "ideological and political education in curriculum", Xin Xue and Yongqiang Gao studied the return and orientation of Wushu's education at school [8]. Carrying out the ideological and political education in curriculum should handle the relationship between explicit education and implicit education, teaching methods and teaching content, value rationality and instrumental rationality [9]. The implementation of the ideological and political education in curriculum also needs to focus on promoting management synergy, discipline synergy and innovation synergy [10].

Based on the analysis and research on the current ideological and political education in curriculum, this paper studies the implementation ideas of the ideological and political education in curriculum of introduction to software engineering, and then gives the key measures of the implementation of the ideological and political education in curriculum. We also discuss the curriculum knowledge content and the ideological and political education materials contained in it, propose the integration points of ideological and political 
mapping, and give corresponding teaching method and expected results.

\section{THE IMPLEMENTATION IDEAS OF THE IDEOLOGICAL AND POLITICAL EDUCATION IN CURRICULUM}

The implementation ideas of the ideological and political education in curriculum of introduction to software engineering is as follows.

\section{A. Implementing the Ideological and Political Education in Curriculum Based on the Objectives of the Course}

The ideological and political teaching of professional courses cannot leave the course itself. Each course has its own positioning in talent cultivation. The ideological and political education in curriculum of introduction to software engineering will also be implemented under the cultivation objectives of itself. The cultivation objective of this course is to enable students to master the basic principles and techniques of software engineering, master modern software development methods and procedures, understand the development direction of various fields of software engineering, and master how to develop software projects and develop with engineering methods, and master the processes, guidelines, standards, and specifications that should be followed during the software development process to provide guidance on how to engage in software development in the future. The moral education goal of this course is to integrate the ideological and political education in the curriculum, establish the morality of students, cultivate the patriotism, social responsibility, solidarity and cooperation spirit, hardworking attitude, enterprising spirit, careful and rigorous work style and innovative consciousness.

\section{B. Implementing the Ideological and Political Education in Curriculum Based on Technological Development}

The development of software technology has been changing with each passing day. Through the historical review of software technology development and the latest trend analysis, students' sense of innovation and the spirit of serious research and exploration can be cultivated.

\section{Implementing the Ideological and Political Education in Curriculum Based on Designing and Developing Project}

The "introduction to software engineering" combines a large number of project examples, through the project feasibility study, requirements analysis, prototype design, overall design, detailed design, software implementation, software testing, and software maintenance to complete the project design and development process. At the same time, software project management is also throughout the whole development process. Through the whole process of project design and development, students' progressive, careful and rigorous work styles and spirits of solidarity can be cultivated.

\section{Implementing the Ideological and Political Education in Curriculum Based on Teaching Platform}

The teaching of "introduction to software engineering" can use the aided teaching platform. The materials and homework of the course can be published through the teaching platform.
The test and examination can also be conducted through the teaching platform. The discussion in the classroom is also assisted by the teaching platform, which can train students' ability of information technology effectively. All the contents of the discussion can be browsed by the teachers and students of the class. Students are responsible for their own opinions, which benefits for cultivating students' sense of social responsibility and integrity.

\section{THE KEy MEASURES OF THE IMPLEMENTATION OF THE}

\section{IDEOLOGICAL AND POLITICAL EDUCATION IN CURRICULUM}

The following key measures can be taken to implement the ideological and political education in curriculum of introduction to software engineering.

- Grasping the cultivation objectives and moral education goals of this course.

- According to the ideological and political goals of "introduction to software engineering", we should think and study conscientiously, and determine the mapping and integration of the curriculum, and collect and design teaching samples.

- Carefully analyze and study the determined ideological and political mapping and integration points, and do instructional design combined with the teaching examples.

- Implementing the course teaching according to the proposed instructional design.

- Summarize the implementation of ideological and political education in curriculum and propose suggestions for improvement in future teaching.

\section{IDEOLOGICAL AND POLITICAL MAPPING INTEGRATION POINT AND INSTRUCTIONAL DESIGN}

According to the knowledge system of "introduction to software engineering”, the teaching contents can be divided into four parts, including software engineering overview, traditional life cycle methodology, object-oriented methodology and software project management. For each part, analyze the material of the ideological and political education, select the teaching contents, study the integration of ideological and political mapping, and carry out the instructional design.

\section{A. Software Engineering Overview}

In the software engineering overview, the analysis of ecommerce, mobile payment, social software and other software that are familiar to students could be regarded as the integration point of ideological and political mapping, it indicates that some domestic software applications have been in the forefront of the world. Teaching methods such as example analysis and classroom discussion combined with the teaching platform can be used in the class. It is expected to stimulate students' patriotic feelings and enhance students' social responsibility. 


\section{B. Traditional Life Cycle Methodology}

Traditional life cycle methodology contains many instructional contents. Most of these teaching contents can be used for ideological and political mapping and instructional design. Table I shows some of the core teaching contents, corresponding ideological and political mapping integration points, teaching methods and expected results. The contents of table I can be used as a reference to implementing the ideological and political education in curriculum of introducing to software engineering when the traditional life cycle methodology is taught.

TABLE I. IDEOLOGICAL AND POLITICAL MAPPING INTEGRATION POINT And Instructional Design of Traditional LifE Cycle MEthodology

\begin{tabular}{|c|c|c|c|}
\hline $\begin{array}{l}\text { Core } \\
\text { teaching } \\
\text { contents }\end{array}$ & $\begin{array}{l}\text { Ideological and } \\
\text { political mapping } \\
\text { integration points }\end{array}$ & $\begin{array}{l}\text { Teaching } \\
\text { methods }\end{array}$ & $\begin{array}{l}\text { Expected } \\
\text { results }\end{array}$ \\
\hline $\begin{array}{l}\text { Feasibility } \\
\text { study }\end{array}$ & $\begin{array}{l}\text { The economic } \\
\text { feasibility analysis of } \\
\text { the software system } \\
\text { shows that the cost- } \\
\text { effectiveness } \\
\text { analysis of software } \\
\text { should be done } \\
\text { carefully. }\end{array}$ & $\begin{array}{l}\text { Example } \\
\text { analysis and } \\
\text { discussion }\end{array}$ & $\begin{array}{l}\text { Cultivate } \\
\text { students' } \\
\text { careful and } \\
\text { rigorous style } \\
\text { of work }\end{array}$ \\
\hline $\begin{array}{l}\text { Requirement } \\
\text { s analysis }\end{array}$ & $\begin{array}{l}\text { Requirements } \\
\text { analysis should } \\
\text { respect users and } \\
\text { meet users' request. }\end{array}$ & $\begin{array}{l}\text { Example } \\
\text { analysis, } \\
\text { discussion } \\
\text { and } \\
\text { investigation }\end{array}$ & $\begin{array}{l}\text { Cultivate } \\
\text { students' } \\
\text { awareness of } \\
\text { respecting } \\
\text { others and } \\
\text { serving the } \\
\text { society }\end{array}$ \\
\hline $\begin{array}{l}\text { Prototype } \\
\text { design }\end{array}$ & $\begin{array}{l}\text { Guide students to } \\
\text { choose software } \\
\text { projects for } \\
\text { prototyping. }\end{array}$ & $\begin{array}{l}\text { Practice on } \\
\text { the computer } \\
\text { and works } \\
\text { show }\end{array}$ & $\begin{array}{l}\text { Cultivate } \\
\text { students' sense } \\
\text { of innovation, } \\
\text { enhance self- } \\
\text { worth and } \\
\text { confidence }\end{array}$ \\
\hline $\begin{array}{l}\text { Software } \\
\text { detailed } \\
\text { design }\end{array}$ & $\begin{array}{l}\text { The detailed design } \\
\text { of the software } \\
\text { means that one } \\
\text { should be down-to- } \\
\text { earth and follow the } \\
\text { plan. }\end{array}$ & $\begin{array}{l}\text { Example } \\
\text { analysis and } \\
\text { discussion }\end{array}$ & $\begin{array}{l}\text { Cultivate } \\
\text { students' } \\
\text { down-to-earth, } \\
\text { careful and } \\
\text { rigorous style } \\
\text { of work } \\
\end{array}$ \\
\hline $\begin{array}{l}\text { Software } \\
\text { testing }\end{array}$ & $\begin{array}{l}\text { Analyzing examples } \\
\text { that led to the grave } \\
\text { loss of life or } \\
\text { property because of } \\
\text { neglecting software } \\
\text { testing. }\end{array}$ & $\begin{array}{l}\text { Example } \\
\text { analysis and } \\
\text { discussion }\end{array}$ & $\begin{array}{l}\text { Cultivate } \\
\text { students' sense } \\
\text { of crisis and } \\
\text { social } \\
\text { responsibility }\end{array}$ \\
\hline $\begin{array}{l}\text { Software } \\
\text { maintenance }\end{array}$ & $\begin{array}{l}\text { Illustrate the } \\
\text { problems of software } \\
\text { maintenance and the } \\
\text { high cost of } \\
\text { maintenance by } \\
\text { reverse examples, } \\
\text { and emphasize the } \\
\text { importance of } \\
\text { software } \\
\text { development in } \\
\text { accordance with the } \\
\text { specifications. }\end{array}$ & $\begin{array}{l}\text { Example } \\
\text { analysis and } \\
\text { discussion }\end{array}$ & $\begin{array}{l}\text { Cultivate } \\
\text { students' } \\
\text { serious and } \\
\text { rigorous style } \\
\text { of work and } \\
\text { the sense of } \\
\text { serving the } \\
\text { society }\end{array}$ \\
\hline
\end{tabular}

\section{Object-oriented Methodology}

Object-oriented methodology is the methodology used by most software companies to develop software in present, and it is also the focus of the "introduction to software engineering" course. This part of the teaching contents reflects the advancement of software development technology. The ideological and political education in curriculum of this part can start from the object-oriented methodology overview, object-oriented analysis and object-oriented design. Table II shows the corresponding ideological and political mapping integration points, teaching methods and expected results of these teaching contents.

TABLE II. IDEOLOGICAL AND POLITICAL MAPPING INTEGRATION POINT AND INSTRUCTIONAL DESIGN OF OBJECT-ORIENTED METHODOLOGY

\begin{tabular}{|c|c|c|c|}
\hline $\begin{array}{l}\text { Core } \\
\text { teaching } \\
\text { contents } \\
\end{array}$ & $\begin{array}{l}\text { Ideological and } \\
\text { political mapping } \\
\text { integration points }\end{array}$ & $\begin{array}{l}\text { Teaching } \\
\text { methods }\end{array}$ & $\begin{array}{l}\text { Expected } \\
\text { results }\end{array}$ \\
\hline $\begin{array}{l}\text { Object- } \\
\text { oriented } \\
\text { methodology } \\
\text { overview }\end{array}$ & $\begin{array}{l}\text { Compare object- } \\
\text { oriented } \\
\text { methodology and life } \\
\text { cycle methodology } \\
\text { to illustrate the } \\
\text { advancement of } \\
\text { object-oriented } \\
\text { methodology and } \\
\text { show the importance } \\
\text { of developing } \\
\text { advanced } \\
\text { technologies. }\end{array}$ & $\begin{array}{l}\text { Lecture and } \\
\text { discussion }\end{array}$ & $\begin{array}{l}\text { Cultivate } \\
\text { students' sense } \\
\text { of innovation } \\
\text { and the spirit } \\
\text { of carefulness } \\
\text { and } \\
\text { exploration }\end{array}$ \\
\hline $\begin{array}{l}\text { Object- } \\
\text { oriented } \\
\text { analysis }\end{array}$ & $\begin{array}{l}\text { Select the system } \\
\text { closely related to } \\
\text { society and do } \\
\text { requirements } \\
\text { analysis by object- } \\
\text { oriented method, } \\
\text { indicating that } \\
\text { requirements } \\
\text { analysis should } \\
\text { respect users and } \\
\text { meet users' request. }\end{array}$ & $\begin{array}{l}\text { Example } \\
\text { analysis, } \\
\text { discussion } \\
\text { and } \\
\text { investigation }\end{array}$ & $\begin{array}{l}\text { Cultivate } \\
\text { students' } \\
\text { awareness of } \\
\text { respecting } \\
\text { others and } \\
\text { serving the } \\
\text { society, and } \\
\text { the spirit of } \\
\text { teamwork }\end{array}$ \\
\hline $\begin{array}{l}\text { Object- } \\
\text { oriented } \\
\text { design }\end{array}$ & $\begin{array}{l}\text { Illustrate the } \\
\text { consistency of } \\
\text { design and analysis } \\
\text { in object-oriented } \\
\text { methodology, and } \\
\text { guide students to do } \\
\text { things consistently. }\end{array}$ & $\begin{array}{l}\text { Teaching } \\
\text { and } \\
\text { discussion }\end{array}$ & $\begin{array}{l}\text { Cultivate } \\
\text { students to } \\
\text { work } \\
\text { consistently } \\
\text { and do adhere } \\
\text { to the } \\
\text { conclusion }\end{array}$ \\
\hline
\end{tabular}

\section{Software project management}

In software project management, the analysis of the importance of teamwork in software project management could be regarded as the integration point of ideological and political mapping. Teaching methods such as Lecture and classroom discussion can be used in the class. It is expected to cultivate students' teamwork spirit and the sense of serving the society.

\section{The Related TEACHING Resources of IDEOLOGICAL AND POLITICAL EDUCATION IN CURRICULUM}

The use of the related teaching resources of ideological and political education in curriculum of introduction to software engineering is as follows.

- Search and organize various forms of teaching resources, including but not limited to videos, cases, projects, electronic teaching plans, network resources, etc. 
- Relevant teaching resources can be published through the online teaching platform.

- Use a variety of teaching resources in the classroom based on teaching requests. There should be a copyright awareness when using these teaching resources, which is actually a part of the ideological and political education in curriculum.

\section{CONCLUSION}

The implementation of ideological and political education in curriculum of professional courses in colleges and universities has been more and more widely recognized. Taking "introduction to software engineering" as an example, we propose a strategy for implementing ideological and political education in curriculum of professional courses. According to this strategy, the ideological and political education in curriculum was implemented in the "introduction to software engineering" course of computer science and technology specialty. It has achieved good results since the implementation of ideological and political education in curriculum. First of all, the spiritual outlook of the students has been greatly improved; most of the students have enhanced their self-confidence and cultivated the spirit of teamwork and courageously struggle. Secondly, the students' sense of social responsibility and patriotism have also been greatly improved. Finally, the student's academic performance has also been improved invisibly. The average score of the final exams for the students who implemented the ideological and political education in curriculum was $10.14 \%$ higher than that of the students who did not implement the ideological and political education in curriculum. In the future, it is necessary to continue to expand from depth and breadth in implementing the ideological and political education in curriculum in professional courses. To expand from the depth, it is necessary to carefully explore the combination of ideological and political education in curriculum for specific professional courses to achieve a better fit. Expanding from breadth, the ideological and political education in curriculum can be implemented in more courses.

\section{REFERENCES}

[1] Hong Lin, “Teaching Strategies for the Ideological and Political Course in Colleges from the Perspective of Constructivism Teaching," Educational Sciences: Theory \& Practice, vol. 18(5), pp. 1277-1284, October 2018

[2] Dongbing Lu, "Research-based Teaching Model of Ideological and Political Course under Computer Network Environment,” Educational Sciences: Theory \& Practice, vol. 18(5), pp. 1784-1791, October 2018.

[3] Xiangxue Kong, “Analysis of the Practical Teaching Mode of Ideological and Political Courses in Colleges and Universities from the Perspective of 'Broad Ideology and Politics',' 2019 International Conference on Arts, Management, Education and Innovation, vol. 6, pp. 1094-1097, January 2019.

[4] Yajuan Huang, "The effectiveness evaluation principle and the dimension construction of ideological and political theory course teaching in colleges and universities,” Agro Food Industry Hi-tech, vol. 28(3), pp. 46-50, May-June 2017.

[5] Yi Liu and Xiaobo Liu, "The Enhancement of Ideological and Political Course Teaching Methods of Strengthening Traditional Virtue Education,” Agro Food Industry Hi-tech, vol. 28(3), pp. 1165-1168, May-June 2017.

[6] Xiang Huang, Min Liu, Pengxiang Huang and Tianxiang Huang, "Effective Integration of College Courses: Ideological and Political Education in Entrepreneurship Curriculum," Educational Sciences: Theory \& Practice, vol. 18(6), pp. 3744-3752, December 2018.

[7] Jinxing Shen, Junjie Qi, Genghua Ma and Changjiang Zheng, "Ideological and Political Education in Curriculum of Traffic Engineering: An Example of Traffic Environmental Impact Assessment Course,” Educational Sciences: Theory \& Practice, vol. 18(6), pp. 2864 2873, December 2018.

[8] Xin Xue and Yongqiang Gao, “The Return and Orientation of School Wushu's Education under the Concept of 'Curriculum with Thought and Politics’ in the New Era,’ Journal of Nanjing Sports Institute, vol. 2(5), pp. 74-80, May 2019. (In Chinese)

[9] Wuhua He, Yunxia Zhang and Xiaofang Yang, "On Three Pairs of Relationship in Ideological and Political Education,” Journal of Hangzhou Dianzi University (Social Sciences), vol. 14(6), pp. 60-64, December 2018. (In Chinese)

[10] Lin Yang, "Three Aspects about Ideology and Politics of Courses in Colleges and Universities,” Journal of Gannan Normal University, vol. 20(5), pp. 126-129, July 2019. (In Chinese) 